\title{
Influence of soil application and spraying of salicylic acid on improving growth and leaf mineral content of olive seedling grow under saline condition
}

\author{
Laila F.Hagagg ${ }^{1}$, M.I.F. Fawzi ${ }^{1}$, M.F.M., Shahin ${ }^{1}$, A.B. El-Sayed ${ }^{2}$ and Eman S. El-Hady ${ }^{1}$ \\ ${ }^{1}$ Pomology Department, Agricultural and Biological Research Division, National Research Centre, \\ 33 El Buhouth St., 12622 Dokki, Giza, Egypt. \\ ${ }^{2}$ Fertilization Technology Department, Agricultural and Biological Research Division, National \\ Research Centre, 33 El Buhouth St., 12622 Dokki, Giza, Egypt
}

Received: 17 Oct. 2019/ Accepted 25 Nov. 2019 / Publication date: 30 Nov. 2019

\begin{abstract}
The aim of the present investigation was to determine the effect of exogenously application of salicylic acid (SA) on growth and leaf nutrient content of olive seedlings picual cv. irrigated with saline water grow in shade house. Seedlings subjected during two growth seasons (2016-2017) to salicylic acid (SA) which applied as foliar and soil application at three concentrations $(0,200$, and 400 $\mathrm{ppm})$ on olive seedlings cv. Picual grown under three levels of salinity (0, 2000, $4000 \mathrm{ppm})$. At the end of each growth season different vegetative growth parameters (plant height increment, leaf dry weight, leaves moist percentage, leaves no. and shoots no.) were determined. Moreover, leaf nutrient status were been estimated. Obtained results indicated that, vegetative growth parameters of olive seedlings cv. Picual show a negative response when irrigated with saline water up to $2000 \mathrm{ppm}$ and increasing salinity in irrigation water from 2000 to $4000 \mathrm{ppm}$ tended to significantly decrease vegetative growth parameters. Where, exogenous application of salicylic acid with $200 \mathrm{ppm}$ (sparing + soil application) on olive seedlings improved most vegetative studied parameters. Also, current study concluded that, exogenous application of salicylic acid on saline stressed picual olive seedling increased nitrogen and potassium content in leaves than untreated once. Whereas, no effect noticed of exogenous application salicylic acid on the percentage of phosphor content on leaves of saline stressed picual olive seedling.
\end{abstract}

Keywords: : saline water, salicylic acid, antioxidants, foliar application, soil application, picual olive cv., seedlings, growth performance, nutrient status, seedlings, NPK.

\section{Introduction}

Olive tree (Olea europaea L.) trees is considered as middling salt tolerant (Maas, 1986) and is usually cultivated in dry lands in semi-arid regions with Mediterranean climate, where infrequent and rare rainfalls led to decrease in the fruit yield. For that, application of irrigation programs in olive farms increasing yields and profits (Orgaz and Fereres, 2004). Irrigation olive orchids with high saline water are often being applied without looking to the negative effects on vegetative growth and productivity of olive tree. Plants response to high concentrations of salinity is complex and includes changes in morphology, physiology and metabolism process (Parida and Das, 2005). The effect of stress is usually recognized as a reduction in photosynthesis process and growth related with modification in nitrogen and carbon metabolism (Mwanamwenge et al., 1999). Olive tree tolerate salt stress by operating the mechanisms of salt-exclusion in the roots. Olive trees leaf are more sensitive to sodium than chloride, especially at high levels of salinity (Aragüés et al., 2005). Generally high levels of salinity reduce olive trees yield (Gucci and Tattini, 1997).

It is well known that mineral nutrients acting antagonistically or synergistically may imbalance the nutrition of plants grown under saline condition. Higher absorption of sodium and chloride by plant tissues under salin condition caused shortage in most nutrients (Grattan and Grieve, 1999; Subbarao et al., 2003; Hu et al., 2005; Ashraf et al., 2010). Under saline conditions sodium induced blockage or reduced activity of membrane ion transporters which induced reduction in uptake of mineral nutrients. Also, potassium uptake is troubled by salinity subsequently reducing potassium/sodium ratio (Izzo et al., 1991; Subbarao et al., 1990). However, high potassium/sodium 
ratio in plants grown under salt stress considered important selection criterion for salt tolerance (Shah et al., 1987; Reynolds et al., 2005).

Plant hormones influence plant growth in different ways through a number of physiological/biochemical processes in plants exposed to abiotic and biotic stresses (Reymond and Farmer, 1998; Steduto et al., 2000; Ashraf et al., 2008, 2010). Exogenously application of salicylic acid considered main signal molecule implicated in both induction of systemic resistance and local defense reactions response of plants after salt stress (Loake and Grant, 2007). Salicylic acid considered is one such plant growth regulators, which share in the regulation number of physiological proceedings in the plant (Dolatabadian et al., 2008; Ashraf et al., 2010). Interestingly, the majority of salicylic acid organize abiotic stresses in plants depending on antioxidative responses, which indicates that salicylic acid working as internal signal molecule that interacts with reactive oxygen species (ROS) signal pathways and could regulate physiological adaptation to some environmental stresses, including oxidation damage (Borsani et al., 2001). salicylic acid Protect plants from oxidative damage through increasing activity of antioxidant enzyme and decreasing level of reactive oxygen species and lipid peroxidation (Wang et al., 2006; Shi and Zhu, 2008; Sharhrtash et al., 2011). salicylic acid regulates some key plant functions such as stomatal functioning (Aldesuquy et al., 1998), ion uptake and transport (Glass, 1975; Kaydan et al., 2007), photosynthesis (Noreen and Ashraf, 2008), water relations (Barkosky and Einhellig, 1993), production rate and content of anthocyanin and chlorophyll (Khurana and Maheshwari, 1980). It also increases growth (Arfan et al., 2007; Ashraf et al., 2010).

All these functions have a significant role in plant tolerance to salinity (Noreen and Ashraf, 2008; Noreen et al., 2009; Dolatabadian et al., 2008; Abreu and Munne-bosch, 2009; Ashraf et al., 2010). Inducing salt stress tolerance by using salicylic acid depends upon the concentration of salicylic acid applied (Noreen and Ashraf, 2008) or the developmental phase of plants (Borsani et al., 2001). In view of all the above reports, the principal objective of the present study was to appraise whether varying levels of exogenously applied salicylic acid could alleviate the adverse effects of salt stress on growth, and leaf nutrient content in picual olive seedlings.

\section{Materials and Methods:}

This work was carried out in the experimental research shade house of National Research Centre, Dokki, Giza, Egypt during 2016- 2017. For this purpose, healthy one-year-old homogeneous self-rooted $(40 \mathrm{~cm})$ olive seedlings picual $\mathrm{cv}$. produced through mist propagation system was used. The seedlings were planted in 10 liter black polyethylene bags with $30 \mathrm{~cm}$ diameter fooled with washed sand mixed very well with peat moos $(2: 1, \mathrm{w} / \mathrm{w})$, Olive seedlings were irrigated twice weekly. Picual olive seedlings were fertilized with recommended dose (1 gm/seedling/week) of conventional fertilizers which add as crystalon (20:20:20 NPK). salicylic acid (SA) applied as foliar and soil application at three concentrations $(0,200$, and $400 \mathrm{ppm})$ on olive seedlings $\mathrm{cv}$. Picual grown under three levels of salinity $(0,2000,4000 \mathrm{ppm})$ in irrigation water, Salt solution comprised from $(3 \mathrm{NaCl}$ : $1(1 \mathrm{MgCl} 2: 1 \mathrm{CaCl} 2)$. Treatments were arranged in randomized complete block design with five replicates for each treatment and each replicate was comprised of three seedlings.

\begin{tabular}{ll}
\hline salicylic acid treatments & Application method of salicylic acid \\
\hline First treatment & Sparing with tap water + soil application with tap water \\
Second treatment & Sparing $200 \mathrm{ppm}+$ soil application $200 \mathrm{ppm}$ \\
Third treatment & Sparing $200 \mathrm{ppm}+$ soil application $400 \mathrm{ppm}$ \\
Forth treatment & Sparing $400 \mathrm{ppm}+$ soil application $200 \mathrm{ppm}$ \\
Fifth treatment & Sparing $400 \mathrm{ppm}+$ soil 400 application ppm \\
\hline
\end{tabular}

\section{Salinity levels:}

1- Tap water (control)

2- $2000 \mathrm{ppm}$

3- $4000 \mathrm{ppm}$

At the end of September, plants of each treatment were removed genteelly with their root system to estimate and record the following data: 


\section{Vegetative growth parameters:}

1. Seedling height increment $\%$ which was calculated monthly after month of each spray and at the end of experiment (at the end of September).

2. Shoots number per seedling.

3. Leaves number per seedling.

4. Leaves dry weight $\%$.

5. Leaves moist $\%$.

\section{Leaves mineral content:}

Nitrogen $(\mathrm{N})$ and phosphorus $(\mathrm{P})$ in leaves were calorimetrically determined according to the methods described by Bremner, et al (1982), and Olsen and Sommers (1982), respectively. Potassium (K) was determined flame photometrically according to the method advocated by Jackson, et al (1970).

\section{Data Analysis:}

The average data of the two season were subjected to analysis of variance and the method of Duncan's was used to differentiate means (Duncan, 1959).

\section{Result}

Effect of spraying and soil application of Salicylic acid on vegetative growth parameters of picual olive seedlings irrigated with saline water:

\section{1-Seedling height increment \% :}

Data in Table (1) showed that using salicylic acid with spraying $200 \mathrm{ppm}$ plus $200 \mathrm{ppm}$ as soil addition gave the highest seedling across all salinity levels. On the other hand, control treatment (0ppm salicylic acid) gave the lowest plants compared with other treatments across all salinity treatments. The highest value of plant height was obtained with using $2000 \mathrm{ppm}$ saline water with insignificant differences between control and $2000 \mathrm{ppm}$ salinity across all salicylic acid treatments. Interaction between treatments of salicylic acid and salinity levels was significant. Furthermore, seedlings highest were obtained with spraying $200 \mathrm{ppm}$ plus $200 \mathrm{ppm}$ soil addition of salicylic acid treatment and2000 ppm salinity levels (Table 1).

Table 1: Effect of Salicylic acid and salinity level and their interaction on seedling height increment \%of picual olive seedlings.

\begin{tabular}{|c|c|c|c|c|}
\hline Salicylic acid & $\begin{array}{l}\text { Without } \\
\text { salinity }\end{array}$ & 2000 ppm & 4000 ppm & Mean \\
\hline O ppm & 74.33 def & $84.33 \mathrm{bc}$ & $68.67 \mathrm{f}$ & $75.78 \mathrm{D}$ \\
\hline Sparing 200 ppm + soil application 400 ppm & $82.67 \mathrm{bc}$ & 74.33 def & $84.00 \mathrm{bc}$ & $80.33 \mathrm{C}$ \\
\hline Sparing 400 ppm + soil application 200 ppm & $86.67 \mathrm{~b}$ & 80.00 bcde & $81.00 \mathrm{bcd}$ & $82.56 \mathrm{BC}$ \\
\hline Sparing 400 ppm + soil 400 application ppm & $99.33 \mathrm{a}$ & 80.00 bcde & 73.00 ef & $84.11 \mathrm{~B}$ \\
\hline
\end{tabular}

\section{2- Leaves number per seedling:}

No. of leaves per seedling varied according to salicylic acid treatments as well as salinity levels. Table 2 indicates that using $0 \mathrm{ppm}$ salicylic acid treatment gave the highest average of No. of leaves per seedling across all salinity treatments. Using saline water (2000 ppm) significantly gave the highest No. of leaves per seedling as compared other salinity level. Interaction between salicylic acid treatments and salinity levels was significant. Furthermore, the highest No. of leaves per seedling were obtained at tenth treatment by using salicylic acid treatment (Spring $400 \mathrm{ppm}+$ soil 400 ppm) and $2000 \mathrm{ppm}$ salinity levels (Table 2). 
Table 2: Effect of Salicylic acid and salinity level and their interaction on Leaves number per seedlingof picual olive seedlings.

\begin{tabular}{lcccc}
\hline \multicolumn{1}{c}{ Salinity } & $\begin{array}{c}\text { Without } \\
\text { salinity }\end{array}$ & $\mathbf{2 0 0 0} \mathbf{~ p p m}$ & $\mathbf{4 0 0 0} \mathbf{~ p p m}$ & Mean \\
\hline Salicylic acid & $249.67 \mathrm{c}$ & $265.00 \mathrm{c}$ & $261.67 \mathrm{c}$ & $258.78 \mathrm{~A}$ \\
Sppm & $225.33 \mathrm{~d}$ & $214.00 \mathrm{~d}$ & $189.67 \mathrm{e}$ & $209.67 \mathrm{C}$ \\
Sparing 200 ppm + soil application 200 ppm & $161.00 \mathrm{f}$ & $228.67 \mathrm{c}$ & $145.33 \mathrm{f}$ & $178.33 \mathrm{D}$ \\
Sparing 400 ppm + soil application 400 ppm & $156.00 \mathrm{f}$ & $214.67 \mathrm{~d}$ & $146.00 \mathrm{f}$ & $172.22 \mathrm{D}$ \\
Sparing 400 ppm + soil 400 application ppm & $293.67 \mathrm{~b}$ & $310.00 \mathrm{a}$ & $76.33 \mathrm{~g}$ & $226.67 \mathrm{~B}$ \\
Mean & $217.13 \mathrm{~B}^{\prime}$ & $246.47 \mathrm{~A}^{\prime}$ & $163.8 \mathrm{C}^{\prime}$ & \\
\hline
\end{tabular}

\section{3- Shoots number per seedling:}

The best value of No. of shoots per seedling was obtained in second salicylic acid treatment (Spring $200 \mathrm{ppm}+$ soil $200 \mathrm{ppm}$ ) across all salinity levels (Table 3). Control treatment (tap water) recorded the maximum No. of shoots per seedling compared to the other salinity level across salicylic acid treatments (table 3). The highest No. of shoots per seedling was obtained from twelve treatment which provided salicylic acid (Spring $200 \mathrm{ppm}+$ soil $200 \mathrm{ppm}$ ) and saline water (4000 ppm).

Table 3: Effect of salicylic acid and salinity level and their interaction on number of shoots per seedling of picual olive seedlings.

\begin{tabular}{|c|c|c|c|c|}
\hline Salicylic acid & $\begin{array}{l}\text { Without } \\
\text { salinity }\end{array}$ & 2000 ppm & 4000 ppm & Mean \\
\hline 0 ppm & $6.00 \mathrm{def}$ & $8.00 \mathrm{~cd}$ & $8.33 \mathrm{~cd}$ & $7.44 \mathrm{~B}$ \\
\hline Sparing 200 ppm + soil application 200 ppm & $13.33 \mathrm{~b}$ & $9.00 \mathrm{c}$ & $16.00 \mathrm{a}$ & $12.78 \mathrm{~A}$ \\
\hline Sparing $200 \mathrm{ppm}$ + soil application $400 \mathrm{ppm}$ & $8.00 \mathrm{~cd}$ & $5.00 \mathrm{ef}$ & $8.00 \mathrm{~cd}$ & $7.00 \mathrm{~B}$ \\
\hline Sparing $400 \mathrm{ppm}$ + soil application $200 \mathrm{ppm}$ & 7.67 cde & $8.33 \mathrm{~cd}$ & $6.67 \mathrm{cdef}$ & $7.56 \mathrm{~B}$ \\
\hline Sparing 400 ppm + soil 400 application ppm & $11.67 \mathrm{~b}$ & $6.00 \mathrm{def}$ & $4.00 \mathrm{f}$ & $7.22 \mathrm{~B}$ \\
\hline Mean & $9.33 \mathrm{~A}^{\prime}$ & $7.27 \mathrm{~B}^{\prime}$ & $8.6 \mathrm{~A}^{\prime}$ & \\
\hline
\end{tabular}

\section{4- Leaves dry weight \%:}

Table (4) shows the effect of different concentration of salicylic acid treatments and salinity levels on dry weight percentage of leaves of the two olive seedlings. Dry weight percentage of olive seedlings leaves varied according to the treatments applied. Data Table (4) represented that foliar + soil application of salicylic acid with $200 \mathrm{ppm}$ accept the highest average leaves dry weight percentage across all salinity levels. On the contrary, the lowest leaves dry weight $\%$ significant indicated with olive seedling grow across all salinity levels without using salicylic acid treatments. Tap water gave the maximum leaves dry weight \% compared with other salinity level across all salicylic acid treatments. The interaction between salicylic acid treatments and salinity levels showed significant differences.

Table 4: Effect of salicylic acid and salinity level and their interaction on leaves dry weight $\%$ of picual olive seedlings.

\begin{tabular}{lcccc}
\hline \multicolumn{1}{c}{ Salinity } & $\begin{array}{c}\text { Without } \\
\text { salinity }\end{array}$ & $\mathbf{2 0 0 0} \mathbf{~ p p m}$ & $\mathbf{4 0 0 0} \mathbf{~ p p m}$ & Mean \\
\hline Salicylic acid & $64.17 \mathrm{f}$ & $64.31 \mathrm{f}$ & $62.75 \mathrm{~g}$ & $63.74 \mathrm{D}$ \\
Sparing 200 ppm + soil application 200 $\mathbf{~ p p m}$ & $69.15 \mathrm{ab}$ & $68.09 \mathrm{~cd}$ & $67.18 \mathrm{de}$ & $68.14 \mathrm{~A}$ \\
Sparing 200 ppm + soil application 400 $\mathbf{~ p p m}$ & $64.06 \mathrm{f}$ & $68.46 \mathrm{bc}$ & $63.82 \mathrm{f}$ & $65.45 \mathrm{C}$ \\
Sparing 400 ppm + soil application 200 ppm & $69.74 \mathrm{a}$ & $67.35 \mathrm{de}$ & $62.74 \mathrm{~g}$ & $66.61 \mathrm{~B}$ \\
Sparing 400 ppm + soil 400 application $\mathbf{~ p p m}$ & $68.43 \mathrm{bc}$ & $66.84 \mathrm{e}$ & $69.85 \mathrm{a}$ & $63.74 \mathrm{~A}$ \\
Mean & $67.11 \mathrm{~A}^{\prime}$ & $67.01 \mathrm{~A}^{\prime}$ & $65.27^{\prime}$ & \\
\hline
\end{tabular}

\section{Leaves moist \% :}

The highest percent of leaves moisture was obtained in the first salicylic acid treatment across all salinity treatments. Moreover, percent of leaves moisture at $4000 \mathrm{ppm}$ salinity level was significantly higher than other salinity levels across all salicylic acid treatments. Moreover, the fourth 
interaction treatment had the maximum percent of leaves moisture compared to the other interaction treatments (Table 5).

Table 5: Effect of salicylic acid and salinity level and their interaction on leaves moist \% of picual olive seedlings.

\begin{tabular}{|c|c|c|c|c|}
\hline Salicylic acid & $\begin{array}{l}\text { Without } \\
\text { salinity }\end{array}$ & 2000 ppm & 4000 ppm & Mean \\
\hline O ppm & $35.83 \mathrm{~b}$ & $35.69 \mathrm{~b}$ & $37.25 \mathrm{a}$ & $36.26 \mathrm{~A}$ \\
\hline Sparing 200 ppm + soil application 400 ppm & $35.94 \mathrm{~b}$ & 31.54 ef & $36.18 \mathrm{~b}$ & $34.55 \mathrm{~B}$ \\
\hline Sparing 400 ppm + soil application 200 ppm & $30.26 \mathrm{~g}$ & $32.65 \mathrm{~cd}$ & $37.26 \mathrm{a}$ & $33.39 \mathrm{C}$ \\
\hline Sparing 400 ppm + soil 400 application ppm & 31.57 ef & $33.16 \mathrm{c}$ & $30.15 \mathrm{~g}$ & $31.63 \mathrm{D}$ \\
\hline
\end{tabular}

Effect of exogenous spraying and soil application of Salicylic acid on Leaf mineral content of picual olive seedlings irrigated with saline water:

\section{1- Leaf nitrogen percent:}

Data in Table (6) represented that the leaf nitrogen content diverse depending on salicylic acid treatments as well as salinity levels. Also data demonstrated that fourth treatment of salicylic acid significantly achieved the highest average leaf nitrogen content across all salinity levels. While, irrigation with tap water significantly gave the highest average leaf nitrogen content across all salicylic acid treatments. Given the interaction between salicylic acid and salinity there were significant differences. Results in Table (6) indicated that, the lowest and highest leaf nitrogen content values were indicated with olive seedling treated with first and fourth salicylic acid treatments respectively.

Table 6: Effect of salicylic acid and salinity level and their interaction on leaf nitrogen percent of picual olive seedlings.

\begin{tabular}{|c|c|c|c|c|}
\hline Salicylic acid & $\begin{array}{l}\text { Without } \\
\text { salinity }\end{array}$ & 2000 ppm & 4000 ppm & Mean \\
\hline 0 ppm & $1.68 \mathrm{~h}$ & $1.80 \mathrm{~g}$ & $1.85 \mathrm{fg}$ & $1.78 \mathrm{E}$ \\
\hline Sparing 200 ppm + soil application 200 ppm & $2.35 \mathrm{ab}$ & $2.14 \mathrm{~d}$ & $2.18 \mathrm{~cd}$ & $2.22 \mathrm{~B}$ \\
\hline Sparing 200 ppm + soil application 400 ppm & $2.17 \mathrm{~cd}$ & $2.01 \mathrm{e}$ & $1.96 \mathrm{e}$ & $2.04 \mathrm{D}$ \\
\hline Sparing 400 ppm + soil application 200 ppm & $2.45 \mathrm{a}$ & $2.23 \mathrm{~cd}$ & $2.35 \mathrm{ab}$ & $2.35 \mathrm{~A}$ \\
\hline Sparing 400 ppm + soil 400 application ppm & $2.26 \mathrm{bc}$ & $2.13 \mathrm{~d}$ & $1.94 \mathrm{ef}$ & $2.11 \mathrm{C}$ \\
\hline
\end{tabular}

\section{2- Leaf phosphorus percent.}

Table (7) revealed that the effect of different treatments of salicylic acid on leaf phosphorus content of olive seedling grow under the three salinity levels was significant. Also data represented that the third treatment of salicylic acid significantly achieved the highest average of leaf phosphorus content across all salinity levels. Average leaf phosphorus content of olive seedling irrigated with tap water and $2000 \mathrm{ppm}$ had insignificant differences across all salicylic acid treatments. Also the differences between interaction treatments were insignificant.

Table 7: Effect of Salicylic acid and salinity level and their interaction onleaf phosphorus percent of picual olive seedlings.

\begin{tabular}{|c|c|c|c|c|}
\hline Salicylic acid & $\begin{array}{l}\text { Without } \\
\text { salinity }\end{array}$ & 2000 ppm & 4000 ppm & Mean \\
\hline 0 ppm & $0.035 \mathrm{a}$ & $0.038 \mathrm{a}$ & $0.037 \mathrm{a}$ & $0.037 \mathrm{C}$ \\
\hline Sparing 200 ppm + soil application 400 ppm & $0.049 \mathrm{a}$ & $0.049 \mathrm{a}$ & $0.038 \mathrm{a}$ & $0.045 \mathrm{~A}$ \\
\hline Sparing 400 ppm + soil application 200 ppm & $0.046 \mathrm{a}$ & $0.045 \mathrm{a}$ & $0.035 \mathrm{a}$ & $0.042 \mathrm{~B}$ \\
\hline Sparing 400 ppm + soil 400 application ppm & $0.039 \mathrm{a}$ & $0.037 \mathrm{a}$ & $0.035 \mathrm{a}$ & $0.037 \mathrm{C}$ \\
\hline
\end{tabular}




\section{3- Leaf potassium percent:}

Data in Table (8)indicated that olive seedlings treated with the fourth treatment of salicylic acid (Sparing $400 \mathrm{ppm}+$ soil application $200 \mathrm{ppm}$ ) gave the highest average of leaf potassium content across all salinity levels. Whereas olive seedlings irrigated with tap water significantly achieved the highest leaf potassium content significantly compared with the other salinity levels (2000 and 4000 $\mathrm{ppm}$ ). With regard to salinity averages there are insignificant differences clarify between irrigation with tap water and $2000 \mathrm{ppm}$ saline level across all salicylic acid treatments. The interaction was significant between salicylic acid treatments and salinity levels. Also, the highest values of leaf potassium content were found by using the fourth interaction treatment..

Table 8: Effect of salicylic acid and salinity level and their interaction onleaf potassium percent of picual olive seedlings.

\begin{tabular}{lcccc}
\hline \multicolumn{1}{c}{ Salinity } & $\begin{array}{c}\text { Without } \\
\text { salinity }\end{array}$ & $\mathbf{2 0 0 0} \mathbf{~ p p m}$ & $\mathbf{4 0 0 0} \mathbf{~ p p m}$ & Mean \\
\hline Salicylic acid & $1.17 \mathrm{a}$ & $0.98 \mathrm{e}$ & $0.90 \mathrm{e}$ & $1.02 \mathrm{~B}$ \\
Sppm & $1.01 \mathrm{e}$ & $1.10 \mathrm{bc}$ & $0.82 \mathrm{~g}$ & $0.98 \mathrm{C}$ \\
Sparing $200 \mathbf{~ p p m}+$ soil application $\mathbf{2 0 0} \mathbf{~ p p m}$ & $1.06 \mathrm{~cd}$ & $1.11 \mathrm{~b}$ & $0.83 \mathrm{~g}$ & $1.00 \mathrm{~B}$ \\
Sparing $\mathbf{4 0 0} \mathbf{~ p p m}+$ soil application $\mathbf{4 0 0} \mathbf{~ p p m}$ & $1.18 \mathrm{a}$ & $1.11 \mathrm{~b}$ & $1.01 \mathrm{e}$ & $1.10 \mathrm{~A}$ \\
Sparing $\mathbf{4 0 0} \mathbf{~ p p m}+$ soil $\mathbf{4 0 0}$ application $\mathbf{p p m}$ & $1.01 \mathrm{e}$ & $1.00 \mathrm{e}$ & $0.85 \mathrm{~g}$ & $0.95 \mathrm{D}$ \\
Mean & $1.09 \mathrm{~A}^{\prime}$ & $1.06 \mathrm{~A}^{\prime}$ & $0.88 \mathrm{~B}$ & \\
\hline
\end{tabular}

\section{Reference}

Abreu, M.E. and S. Munne-bosch, 2009. Salicylic acid defi ciency in NahG transgenic lines and sid2 mutants increases seed yield in the annual plant Arabidopsis thaliana. J. Exp. Bot. 60, 1261-1271.

Aldesuquy, H.S., A.T. Mankarios and H.A. Awad, 1998. Effect of some antitranspirants on growth, metabolism and productivity of saline-treated wheat plants: Induction of stomatal closure, inhibition of transpiration and improvement of leaf turgidity. Acta Bot. Hung. 41,1-10.

Aragüés, R., J. Puy, A. Royo, and J.L. Espada, 2005. Three-year field response of young olive trees (Olea europaea L., cv. Arbequina) to soil salinity: trunk growth and leaf ion accumulation. Plant Soil 271:265-273.

Arfan, M., H.R. Athar and M. Ashraf, 2007. Does exogenous application of salicylic acid through the rooting medium modulate growth and photosynthetic capacity in differently adapted spring wheat cultivated under salt stress? J. Plant Physiol. 6, 685-694.

Ashraf, M., H.R. Athar, P.J.C. Harris and T.R. Kwon, 2008. Some prospective strategies for improving crop salt tolerance. Adv. Agron. 97, 45-110.

Ashraf, M., N.A. Akram, R.N. Arteca, and M.R. Foolad, 2010. The physiological, biochemical and molecular roles of brassinosteroids and salicylic acid in plant processes and salt tolerance. Crit. Rev. Plant Sci. 29, 162-190.

Barkosky, R.R. and F.A. Einhellig, 1993. Effects of salicylic acid on plant water relationships. J. Chem. Ecol. 19, 237-247.

Borsani O., V. Valpuesta and M.A. Botella, 2001. Evidence for a role of salicylic acid in the oxidative damage generated by $\mathrm{NaCl}$ and osmotic stress in Arabidopsis seedlings. Plant Physiol., 126:10241030.

Bremner, J. M. and C.S. Mulvaney, 1982. Total nitrogen In: Page, A. L., R. H. Miller, and D. R. Keeney (Eds). Methods of Soil Analysis. Part 2, Amer. Soc. Agron. Madison, W. I. USA., pp: 595- 624.

Dolatabadian, A., S.A. Mohammad, M. Sanavy, and M. Sharif, 2008. Effect of salicylic acid and salt on wheat seed germination. Acta Agric. Scandinavica Section B. Soil Plant Sci. 1-9.

Duncan, D.B., 1955. Multiple rang and multiple F test. Biometrics, 11: 1-42.

Glass, A.D.M., 1975. Inhibition of phosphate uptake in barley roots by hydroxyl-benzoic acids. Phytochemistry 14, 2127-2130.

Grattan, S.R. and C.M. Grieve, 1999. Mineral nutrient acquisition and response by plants grown in saline environments. In: Pessarakli, M. (ed.). Handbook of plant and crop stress. 2nd. Marcel Dekker, New York, 203-299.

Gucci, R. and M. Tattini, 1997. Salinity tolerance in olive. Hort. Rev. 21:177-214. 
Hu, Y., J. Fromm, and U. Schmidhalter, 2005. Effect of salinity on tissue architecture in expanding wheat leaves. Planta 220, 838-848.

Izzo, R., F. Navari-izzo and M.F. Quartacci, 1991. Growth and mineral absorption in maize seedlings as affected by increasing $\mathrm{NaCl}$ concentrations. J. Plant Nutr. 14, 687-699.

Jackson, M.L., 1970. Soil Chemical Analysis. Prentic Hall, Englewood Ceiffs, N.J.

Kaydan, D., M. Yagmur and N. Okut, 2007. Effects of salicylic acid on the growth and some physiological characters in salt stressed wheat (Triticum aestivum L.). Tarim Bilimleri Dergisi 13, 114-119.

Khurana, J.P. and S.C. Maheshwari, 1980. Some effects of salicylic acid on growth and fl owering in Spirodela polyrrhiza SP20. Plant Cell Physiol. 21, 923-927.

Loake G. and M. Grant, 2007. Salicylic acid in plant defense-the players and protagonists. Curr. Opi. Plant Biol., 10: 466- 472.

Maas, E.V., 1986. Salt tolerance of plants. Applied Agricultural Research 1:12-26.

Mwanamwenge J., S.P. Loss, K.H.M. Siddique and P.S. Cocks, 1999. Effect of water stress during floral initiation, flowering and podding on the growth and yield of faba bean (Vicia faba L.). Eur. J. Agron., 11, 1-11.

Noreen, S. and M. Ashraf, 2008: Alleviation of adverse effects of salt stress on sunfl ower (Helianthus annuus L.) by exogenous application of salicylic acid: growth and photosynthesis. Pak. J. Bot. 40, 1657-1663.

Noreen, S., Ashraf, M., Hussain, M., and Jamil, A., 2009: Exogenous application of salicylic acid enhances antioxidative capacity in salt-stressed sunfl ower (Helianthus annuus L.) plants. Pak. J. Bot. 41, 473-479.

Olsen, S.R. and L.E. Sommers, 1982. Phosphorus. In: Page. A.L., R.H. Miller, and D.R.Keeney (Eds). Methods of Soil Analysis .Part 2 Amer. Soc. Agron. Madison, W.I. USA., pp: 403-430.

Orgaz, F. and E. Fereres, 2004. Riego. p.269-288. In: D. Barranco, R. Fernández-Escobar and L. Rallo (eds.), El cultivo del olivo. Madrid: Mundi-Prensa.

Parida A.K. and A.B. Das, 2005. Salt tolerance and salinity effects on plants: A Rev. Ecotoxicol. Environ. Safety, 60: 324-349

Reymond, P., and Farmer, E.E., 1998. Jasmonate and salicylate as global signals for defense gene expression. Curr. Opin. Plant Biol. 1, 404-411.

Reynolds, M.P., A. Mujeeb-kazi, and Sawkins, M., 2005. Prospects for utilizing plant-adaptive mechanisms to improve wheat and other crops in drought- and salinity-prone environments. Ann. Appl. Biol. 146, 239-259.

Shah, S.H., J. Gorham, B.P. Forster and R.G. Wyn Jones, 1987. Salt tolerance in the Triticeae: the contribution of the D genome to cation selectivity in hexaploid wheat. J. Exp. Bot. 38, 254-269.

Sharhrtash M., S. Mohsenzadeh, H. Mohabatkar, 2011. Salicylic acid alleviates paraquat oxidative damage in maize seedling. Asian J. Exp. Biol. Sci., 2: 377-382

Shi Q. and Z. Zhu, 2008. Effects of exogenous salicylic acid on manganese toxicity, element contents and antioxidative system in cucumber. Environ. Exp. Bot., 63:317-326.

Steduto, P., R. Albrizio, P. Giorio, and G. Sorrentino, 2000. Gas exchange response and stomatal and non-stomatal limitations to carbon assimilation of sunfl ower under salinity. Environ. Exp. Bot. 44, 243-255.

Subbarao, G.V., C. Johansen, M.K. Jana and J.V.D.K. Rao, 1990. Effects of the sodium/calcium ratio in modifying salinity response of pigeon-pea (Cajanus cajan L.). J. Plant Physiol. 136, 439-443.

Subbarao, G.V., O. Ito, W.L. Berry and R.M. Wheeler, 2003. Sodium: a functional plant nutrient. Crit. Rev. Plant Sci. 22, 391-416.

Wang L.J., S.J. Chen, W.F. Kong, S.H. Li and D.D. Archibold, 2006. Salicylic acid pretreatment alleviates chilling injury and affects the antioxidant system and heat shock proteins of peaches during cold storage. Postharvest. Biol. Technol., 41:244-25. 